DOI: $10.7242 / 1998-2097 / 2018.2 .9$

УДК 39 (397.4)

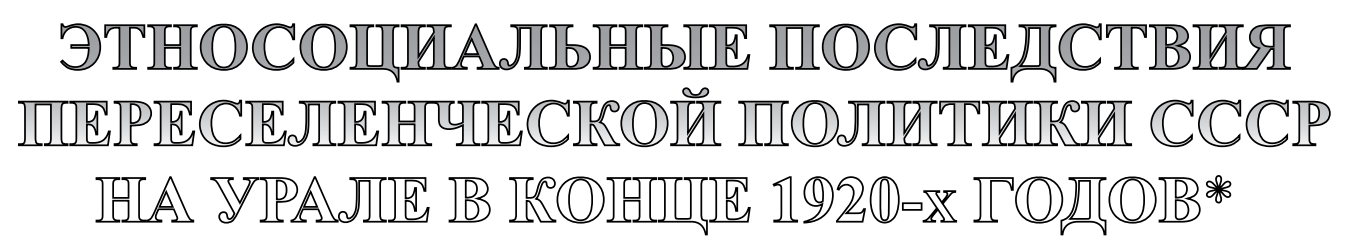

М.С. Каменских, Пермский федеральный исследовательский центр УрО РАН

На основании не публиковавшихся архивных материалов, данных полевых исследований представлен анализ хода и успешности переселенческой кампании на Урале в 1928-1930 годах. Автор рассматривает итоги переселенческой кампании чувашей и украинцев в Уральскую область с точки зрения их влияния на этнический состав населения и формирования этнодисперсных групп региона.

Ключевые слова: государственная национальная политика, Прикамье, переселение, Сарпульский округ, этнодисперсные группь, адаптация, чуваши, украинщь, этносоциальные последствия.

Во второй половине $1920-$ х годов оправившееся от Гражданской войны и еe последствий советское государство приступило к масштабной перестройке народного хозяйства. Начавшиеся вслед за НЭПом индустриализация и коллективизация должны были, по мнению советских идеологов, приблизить страну к социализму. Уралу, как промышленному региону с большим потенциалом, в этой политике принадлежало особое место. Урало-Кузбасский бассейн должен был стать второй промышленной базой страны [19, с. 168-169]. Создание новых рабочих мест требовало дополнительных людских ресурсов, которые невозможно было обеспечить за счет естественного прироста. К тому же в середине 1920 годов дисбаланс в расселении и естественный прирост населения привели к формированию избытка людского ресурса в центральных и западных районах страны. Советские эксперты, ответственные за переселенческую политику, оценивали избыток населения в центральных и западных районах СССР в середине 1920 годов в диапазоне от 10 до 23 млн человек [7, Оп. 1. Д. 2, с. 17-18; Д. 7, с. 25]. В 1925-27 годах самовольный отход на заработки из деревни значительно усилился. По данным Наркомтруда, которые приводит Л.Е. Минц, больше всего отходников выходило из Поволжья и Украинской ССР. Так, из Средне-Волжского района в 1923/1924 годах вышло 104,8 тыс. человек, в 1924/1925 годах - 214,0 тыс. человек, в 1925/1926 годах - 246,4 тыс. человек. Из Украинской ССР за эти же годы соответственно - 148,7 тыс., 379,8 тыс. и 474,9 тыс. человек [12, c. 292-293]. Миграция уже началась стихийно, и отказ от участия государства в ее организации мог привести только к новым крестьянским волнениям. По этой причине советское правительство вернулось

* Статья публикуется в рамках гранта РФФИ 17-11-59003 «Национальная политика РСФСР в 1923-1939 годах: региональный аспект». 
к дореволюционной идее стимулирования миграции из перенаселенных районов Поволжья и Центральной России на Урал, в Сибирь и на Дальний Восток.

Переселенческая кампания этого периода многократно изучалась в историографии как на уроне страны, так и в масштабах Уральского региона. Еще в 1920-е годы эксперты, непосредственно задействованные в планировании переселения, оставили несколько трудов по анализу хода и итогов переселенческой кампании. В работах Л.И. Лубны-Герцыка [16], Л.Е. Минца [12], А.С. Либкинда [15], М.Э. Баранова [8] уже отражены ход и основные этапы реализации переселенческой кампании. На Урале эта тематика освещена в работах Ф. Лебедева [14], Е. Федорова [20]. Большая работа по изучению архивных материалов и опубликованных источников проделана в монографии Н.И. Платунова [18]. Несмотря на приверженность автора идеям марксизма и объяснения всех исторических процессов с точки зрения классовой теории общественного развития, работа содержит обширную источниковую базу и не потеряла своей актуальности. В постсоветский период тематика несколько утратила свою актуальность. Из современных авторов тематики переселения в своих трудах касаются Г.Е. Корнилов $[10,11]$ и О.В. Павлова [17]. Авторы вводят в оборот новые научные данные, используют новейшие методы демографического анализа при учете хода и последствий миграции.

Таким образом, на сегодняшний день хронология, основные этапы, оценки эффективности реализации переселенческой кампании полностью описаны, что позволяет рассматривать отдельные контексты и проявления переселенческой кампании с учетом новейших достижений исторической науки. Перспективными представляются такие аспекты, как анализ личностных стратегий переселенцев, соотношение масштабов добровольного и принудительного переселения, влияние пересе- ленческой кампании на различные стороны повседневности, проблемы адаптации и обустройства переселенцев. Немаловажным представляется и анализ этносоциальных последствий переселения. Как было показано выше, основной поток переселенцев шел из западных районов и Поволжья, приезжающие переселенцы часто были носителями других культур и языков, что затрудняло и без того непростые процессы их адаптации на новом месте.

Реализованная переселенческая кампания значительно изменила этнический состав населения Урала, сформировав этнодисперсные группы на территориях Троицкого и Сарапульского округов Уральской области. В рамках данной статьи будут рассмотрены основные этносоциальные последствия переселенческой кампании и их влияние на этнический облик Пермского Прикамья, особенно его южных районов. Данная проблематика еще не получила освещения в историографии, хотя частично представлена в работах по истории отдельных народов Урала [21, 22].

Имеющийся внушительный корпус опубликованных источников, ряд не публиковавшихся ранее документов о ходе переселения, а также материалы архива Национально-культурного центра чувашей Пермского края (АНКЦЧПК) позволяют по-новому взглянуть на характер переселенческой кампании на Урале в период 1927-1929 годов [1]. Источником, пока не оцененным в должной мере исследователями, является стенограмма совещания по организации переселенческой кампании в 1927 году, сохранившаяся в фондах РГАЭ [7, ОП. 1. Д. 2]. Источник не только содержит базовые документы переселенческой кампании, но и отражает дискуссии участвующих сторон в ходе обсуждения и принятия решений. Регулирование переселенческой кампании, ее ход, обстоятельства реализации и официальные итоги отчасти позволяет реконструировать вышедший в 1925 году сборник 
«Переселенческое дело» [6]. Записанные в ходе полевых экспедиций в Куединском районе 2001-2002 годов семейные предания также дают возможность рассмотреть причины и мотивы миграции, ее последствия для конкретных семей.

Новую переселенческую политику планировалось вести административным путем. Советским органам, уверенным в преимуществах плановой системы, казалось, что формирование земельных фондов и регулированная переброска населения позволят решить проблему перенаселения. Еще на совещании по организации переселенческой кампании в 1927 году один из ее идеологов Н. Турчанинов так видел ход переселения: «Мы должны организованно проводить переселение, проводить его под общественным контролем» [7, Оп. 1. Д. 2, с. 47].

Для реализации переселения был принят Пятилетний перспективный план переселенческих мероприятий на 1928/1929 1932/1933 годы [5, Оп. 1. Д. 1610. Л. 14]. В п. 2 плана «Общие задачи промышленной колонизации на Урале. Первоочередные районы колонизации», сообщалось о подготовке строительства новых «крупнейших» предприятий на Урале: «Все это должно вызвать большой приток рабочей силы и в результате существенного изменения в распределении населения - возникновение новых крупных поселений городского типа и вокруг них целых групп обслуживающих их нужд сельских пунктов» [5, Оп. 1. Д. 1610. Л. 15]. В задачи созданной для этих целей Уральской районной переселенческой организации входила колонизация будущих промышленных центров севера и юга Урала - Нижнетагильского и Верхне-Камского округа, а также Магнитогорского района Троицкого округа. В связи с подготовкой строительства новых «крупнейших» предприятий на Урале планировалось существенно увеличить объемы лесозаготовок. На тот момент они на $75 \%$ велись привозными рабочими из лесных губерний Европейской части России общей численностью свыше 10 тыс. человек. Для обеспечения нужного количества рабочих планировалось переселить 7-8 тыс. семей и создать 150 поселков из расчета 50 дворов на поселок [5, Оп. 1. Д. 1610. Л. 14].

Несмотря на то что национальная политика и поддержка национальных меньшинств в тот период находилась на пике своей реализации[2, с. 2], этнокомпонент в вопросах переселения не учитывался. В стенограмме Всероссийского совещания работников по переселенческому делу видно, что данный вопрос практически не обсуждался. Лишь однажды за три дня работы его коснулся представитель ЦИК Сабиров: «Я хочу присоединить к этим трудностям еще один момент, который никем пока еще не был затронут. Это, товарищи, состав наших поселенцев, который у нас различен по национальному составу. У нас в РСФСР имеется много миллионов мелких национальностей, живущих в тех губерниях, которые дают переселенческий контингент. Каким образом поставить работу среди нацменьшинств, это работу вообще вести очень трудно, даже там где население сидит компактно» [7, Оп. 1. Д. 2, c. 227]. Однако эта реплика осталась без обсуждения и не была услышана.

Когда переселенческая кампания началась, оказалось, что в силу планового происхождения, законная процедура была очень громоздкой. На заседании по переселенческому делу представитель Троицкого округа Алексеев сообщал, что процедура получения документов - «общая волокита, не нужные для переселенца хождения» [7, Оп. 1. Д. 2, с. 227]. Таким образом, переселенцам предлагалась, с одной стороны, сложная бюрократическая процедура официального переселения, с другой - была альтернативная возможность поехать самостоятельно, без сопровождения. Тем более что советское законодательство приравнивало самовольных переселенцев и плановых. Естественно, 
наиболее выгодной стратегией для крестьянина был самовольный переезд.

В итоге начавшееся переселение пошло вразрез с планами. Крестьяне выбирали места для жизни недалеко от родины, обеспеченные лесом, угодьями и сельхозугодьями. Эту ситуацию, в частности, демонстрирует переселение чувашей с территории своего проживания на земли Сарапульского округа. Первыми станциями, которые встречали переселенцев за территорией Поволжья, были ст. Янаул (совр. Башкортостан) и ст. Куеда (совр. административный центр Куединского района Пермского края). Именно туда, а не в отдаленный Троицкий округ направился основной поток переселенцев-чувашей. Проблема актуализировалась в 1928 году, когда в рамках переселенческой кампании был зафиксирован рост самостоятельных переселенцев на территории Сарапульского округа, где не было земельного фонда. 21 мая 1929 года Уралоблисполком проинформировал Наркомзем РСФСР, что фиксируется резкое увеличение «случаев самовольного переселения из Чувашской АССР в Уральскую область, причем движение это идет не только в округа, открытые для переселения, но и в округа, совершенно не имеющие свободных земель, в частности в Сарапульский округ... Такое положение Уральский облисполком считает ненормальным, ведущим к обезземеливанию коренного населения Уральской области» [5, Оп. 1. Д. 1610, с. 41]. В связи с этим Наркомзем РСФСР предложил Наркомзему Чувашской Республики «принять самые решительные меры к прекращению дальнейших выдач переселенческих документов в районы, закрытые для планового переселения, так как это влечет за собой самые тяжёлые последствия» [5, Оп. 1. Д. 1610, с. 12]. Позже Наркомзем ЧАССР сообщил в Сарапульский окрисполком, что переселение в закрытие местности «никогда не поощрялось и никогда не будет поощряться... но переселение в Сарапуль- ский округ, вызванное общеэкономическими условиями, не может быть прекращено в кратчайший срок» [5, Оп. 1. Д. 1610, c. 41]. После этого власти Чувашии и Сарапульского окрисполкома начали совместную политику по остановке миграции. Чувашнаркомзем отослал директиву в районы, согласно которой все, кто покупал землю самовольно, автоматически лишались земельных наделов в Чувашской ССР. Однако у органов власти не было механизмов, чтобы остановить стихийно начавшуюся миграцию. За год с небольшим тысячи чувашей осели в деревнях и сёлах Большеусинского района - Батманы, Большая Уса, Большие Кусты, Бормист, Верх-Дойная, Верхняя Барда, Верхний Тымбай, Дойная, Киловка, Китрюм, Коровино, Пантелеевка, Семеновка, Чиганда Сарапульского округа [22, с. 32]. Следует отметить, что чуваши не создавали новых поселений, а расселялись в уже существующих населенных пунктах, что также подтверждает стихийный, а не административно регламентированный характер этого переселения. Результаты миграции чувашей в Прикамье в конце 1920-х - начале 1930-х годов видны по итогам переписей населения 1926 и 1939 годов. Численность чувашей Прикамья в 1939 году составляла 8821, что в 12 раз больше, чем в 1926 году. При этом доля говорящих на чувашском языке в общем количестве чувашей составила $86,6 \%$ [4, 132-133].

На примере реализации переселенческой политики в Сарапульском округе в 1927-1928 годах видно, что изначально запланированная политика добровольного переселения не дала желаемых результатов, поскольку личные стратегии крестьян, получивших свободу передвижения, не совпадали с планами властей по освоению новых земель на Урале.

Как уже говорилось, переселенческая кампания не только привела к росту населения, но и сформировала этнические анклавы на территориях Сарапульского 
и Троицкого округов Уральской области. Однако никакой серьезной политики в отношении прибывающих национальных меньшинств не предпринималось, что в итоге провоцировало конфликты.

Как свидетельствуют источники и материалы полевых исследований, отношение местного населения к прибывающим было негативным. Среди материалов АНКЦЧПК сохранились воспоминания семьи Яковлевых о первых днях жизни на новом месте. «Воду пили из отдельных кружек, на сенокосе во время перерывов отдыхали в стороне, близко их (чувашей - М.К.) не подпускали. Разговор с другими заводить не надлежало», - говорится в источнике [1, письма семьи Яковлевых]. Из воспоминаний Анны Назаровны и Григория Яковлевича Назарова: «Многое пришлось пережить - терпели унижения, оскорбления, утраты... Жители долго нас чурались, с опаской и недовериям смотрели вслед» [22, с. 36]. Чувашам не разрешалось брать воду из родника, им не продавали скотину, детям не разрешали играть вместе с местными русскими. Во многом такое отношение может объясняться и тем фактом, что на данных территориях проживало старообрядческое население, неохотно шедшее на контакт с внешним миром. Но даже несмотря на это, в начале 1930-х годов в Куединском районе произошло несколько инцидентов между работниками созданных чувашами колхозов и местными жителями.

Самым резонансным стал эпизод, когда работники колхоза «Чуваш» Пантелевского сельсовета Куединского района написали коллективное обращение в отдел нацменьшинств Уралобкома и местную газету «Колхозный путь» [5, Оп. 1. Д. 169, c. 11]. В обращении сообщалось, что в д. Дубленека Пантелевского сельсовета Куединского района руководство колхоза «Вперед» с молчаливого согласия местных властей стало принудительно привлекать для работы на своих участках чувашей из колхоза «Чуваш». Председатель кол- хоза «Вперед» Юрганов даже с помощью револьвера заставлял бригаду женщин чувашек работать. Их бригадиру Борисову за «хорошую работу» он обещал пулю. Сообщалось, что это делается «в связи с ненавистью к национальности чувашей со стороны колхоза «Вперед» [5, Оп. 1. Д. 169, c. 11]. Из показаний работницы колхоза «Чуваш» Анастасии Чугуновой: «Колхозники колхоза «Вперед», видя что нас, перепуганных, пригнали к ним работать, стали над нами же смеяться, говоря, что с вами, чувашами, так и надо поступать. Насмешки со стороны русских были и до этого, мы идем к ним работать (помогать), а они над нами смеются» [5, Оп. 1. Д. 169, с. 18]. Еще одни работник, Никифор Вазанов, сообщил следующее: «...в 1930-31 годах в колхозе «Вперед» чуваш было 40-50 хозяйств, русские нас чуваш стали притеснять и над нами смеяться... колхозники колхоза «Вперед» относятся к нам нехорошо и над чувашами смеются» [5, Оп. 1. Д. 169, с. 18 ].

Позже это дело разбиралось на областном уровне, виновные были наказаны. Однако этот инцидент демонстрирует, насколько сложными были отношения у прибывающих представителей разных национальностей с местным русским старожильческим населением. Можно предположить, что аналогичные процессы могли иметь место и в других районах области. Миграцию украинцев в Троицкий округ, например, красноречиво демонстрирует заметка «Глухой уголок» в официальной газете Троицкого окружкома «Вперед»: «...пос. Ново-Алексеевский Варненского района заселен переселенцами украинцами. В поселке 36 дворов. Молодежи до 100 человек. Работа не ведется совсем. Не читая газет и не слыша живой разумной речи, население питается нелепыми слухами» [3].

Таким образом, переселенческая кампания на территории Пермского Прикамья в 1928-1930 годах не только привела к росту населения, но и сформировала локальные этнодисперсные группы, 
оторванные от мест традиционного проживания и оказавшиеся в иноэтнокультурном окружении. Процесс адаптации этих переселенцев был не просто связан с обустройством на новом месте, но и привел к проблемам в отношениях с местным старожильческим населением. Отсутствие специальной работы в этом направлении спровоцировало ряд инци- дентов и конфликтов на национальной почве. Анализ архивных документов и материалов полевых исследований позволяет раскрыть новые итоги переселенческих кампаний РСФСР 1920-1930 годов. Безусловно, этот сложный процесс, а главное, его итоги и социальные последствия могут быть проанализированы и пересмотрены.

\section{Библиографический список}

1. Архив Национально-культурного центра чувашей Пермского края (АНКЦЧПК)

2. ВКП (б). Резолюция областного совещания партработников нацмен (15-18 мая 1927 г.) - Свердловск: Уралполиграф, 1927. - 19 с.

3. Вперед. Официальное издание Троицкого горкома и райкома ВКП(б), городского и районного Совета депутатов трудящихся. - 1928. - 21 окт.

4. Всесоюзная перепись населения 1939 года: Уральский регион: Сборник материалов / сост. В.П. Мотревич. - Екатеринбург: Изд-во гуманитарного ун-та, 2002. - 600 с.

5. Государственный архив Свердловской области (ГАСО). Ф. Р-88. Исполнительный комитет Свердловского областного Совета народных депутатов г. Свердловск (13.12.1923-21.10.1991)

6. Мини Л.Е. Аграрное перенаселение и рынок труда СССР. - М.-Л.: Гос. изд-во, 1929. - 470 с.

7. Переселенческое дело: сборник декретов и распоряжений по переселению. - М.: Народный комиссариат земледелия, 1927. - 360 с.

8. Российский государственный архив экономики (РГАЭ). Ф. 5675. Учреждения по руководству переселением в СССР. 1925-1942, 1949-1954.

9. Баранов М.Э. Переселение и коллективизация. - М.: Книгосоюз, 1929. - 75 с.

10. Большаков М.А. Задачи и перспективы колонизации // Земельное дело: Сборник статей по вопросам земельной и сельскохозяйственной политики, экономики, техники и организации земельного дела, колонизации и переселения и земельного дела за границей / под ред. А.A. Андреева, М.М. Шульгина. -1923.- № 12. -С. 125.

11. Корнилов Г.Е., Кузьмин А.И. Население Урала. ХХ век. История демографического развития. - Екатеринбург: Изд-во «Екатеринбург», 1996. - 212 с.

12. Корнилов Г.Е., Кузьмин А.И. Этнодемографическое развитие Урала в XIX - XX вв. - Екатеринбург: Изд-во «Екатеринбург», 2000. - 104 с.

13. Лебедев Ф. Механическое движение населения городов Урала // Хозяйство Урала. - 1928. - № 8-9. C. $150-161$.

14. Лебедев Ф. Население Уралобласти // Хозяйство Урала. - 1925. - № 5-6. - С. 121-129.

15. Либкинд А.С. Аграрное перенаселение и коллективизация деревни. - М.: Мосполиграф, 1931. - 196 с.

16. Лубны-Гериыьк Л.И. Что такое перенаселение. - М., 1923. - 100 с.

17. Павлова О.В. Миграции населения на Урале в 1914-1939 гг.: дис. ... канд. ист. наук : 07.00.02. - Екатеринбург, 2004. - 303 с.

18. Платунов Н.И. Переселенческая политика советского государства и ее осуществление в СССР (1917 июнь 1941 гг.). - Томск: Изд-во Томского ун-та, 1976. - 284 с.

19. Урал в панораме XX века / гл. ред. В.В. Алексеев. - Екатеринбург: «СВ-96», 2000. - 496 с.

20. Федоров Е. Переселение на Урал // Хозяйство Урала. - 1928. - № 8-9. С. 6-33.

21. Черных А.В., Голева Т.Г., Каменских М.С., Шевырин С.А. Белорусы в Пермском крае: очерки истории и этнографии. - СПб.: Маматов, 2013. - 260 с.

22. Черных A.В., Каменских М.С. Чуваши в Пермском крае: очерки истории и этнографии. - СПб.: Маматов, 2014. $-272 \mathrm{c}$ 


\title{
ETHNOSOCIAL CONSEQUENCES OF THE RESETTLEMENT POLICY OF THE USSR IN THE URALS IN THE LATE 1920S
}

M.S. Kamenskikh

\author{
Perm Federal Research Center UB RAS
}

In the article, based on unpublished archival materials and and field research, census data materials, the analysis of the progress and success of the resettlement campaign in the Urals in the 1928-1930s are described. The author considers the results of the migration campaign of Chuvash and Ukrainians in the Urals region in terms of their influence on the ethnic structure of the population and the formation of ethno-disperse groups in the region.

Keywords: the national state policy, Perm region, migration, Sarapul district of Ural oblast, ethnodisperse groups, adaptation, Ukranians, Chuvashes, ethno-social consequences.

\section{Сведения об авторе}

Каменских Михаил Сергеевич, кандидат исторических наук, старший научный сотрудник отдела истории, археологии и этнографии, Пермский федеральный исследовательский центр УрО РАН (ПФИЦ УpO РАН), 614900, г. Пермь, ул. Ленина, 13A; e-mail: pomidorrr@mail.ru 